\section{Navigating Social Relationships with Mentors and Peers: Comfort and Belonging among Men and Women in STEM Summer Research Programs}

\author{
Heather A. Daniels, ${ }^{\dagger}$ Sara E. Grineski, ${ }^{\neq *}$ Timothy W. Collins, ${ }^{\S}$ \\ and Angela H. Frederick" \\ 'Department of Sociology, University of California at Merced, Merced, CA 95340; ;Department \\ of Sociology and \$Department of Geography, University of Utah, Salt Lake City, UT 84112; \\ "Department of Sociology and Anthropology, University of Texas at El Paso, El Paso TX 79902
}

\begin{abstract}
Gender disparities in science, technology, engineering, and mathematics (STEM) are well documented, yet little is known about how women and men students establish social relationships with research mentors and peers and how that shapes their experiences in STEM. We conducted a series of interviews with 17 undergraduate students from a Hispanic majority institution regarding their participation in STEM-focused summer research programs at nine universities. Differences in levels of comfort in relationships were present when comparing men and women. Women students expressed comfort in relationships with mentors who provided psychosocial mentoring, were available to answer questions, and were of the same gender; they expressed some social discomfort in informal interactions with mentors. Men students felt comfortable with mentors who provided limited guidance, little psychosocial mentoring, and opportunities for informal interactions. In terms of peer relationships, women sought out the confidence of a few similar peers, while men were comfortable with a wide variety of peers. Men's greater comfort with social relationships seemed to reflect their affinity with the masculine-dominated culture of STEM. For women, cultivating safe spaces through relationships with supportive peers and working with same-gender faculty mentors seemed to mitigate some of the discomforting aspects of their STEM research experiences.
\end{abstract}

\section{INTRODUCTION}

Gender and racial/ethnic disparities in science, technology, engineering, and mathematics (STEM) higher education (Mau, 2016) have led to the creation of many federally and privately funded undergraduate educational programs over the past three decades in the United States in an attempt to level the educational playing field and to plug the leaky STEM pipeline. Many of these intervention programs focus on providing research experiences, as these experiences have been shown to benefit students while increasing their retention in STEM fields (Lopatto, 2004, 2007; Lopatto and Tobias, 2010; Prunuske et al., 2016). Research programs typically happen during the academic year or summer; however, little is known about how differences in men's and women's comfort in social relationships, established through undergraduate research training programs, may differentially influence their experiences in research. These programs have been shown to provide invaluable experiences to underrepresented minority (URM) students that otherwise may be inaccessible to them. Moreover, research programs promote women and URM students' persistence in STEM fields, entrance into graduate programs, and employment in STEM fields (Hunter et al., 2007; Hurtado et al., 2009; Harsh et al., 2012).
Jeff Schinske, Monitoring Editor

Submitted Aug 6, 2018; Revised Jan 23, 2019; Accepted Jan 25, 2019

CBE Life Sci Educ June 1, 2019 18:ar17

DOI:10.1187/cbe.18-08-0150

*Address correspondence to: Sara E. Grineski (sara.grineski@soc.utah.edu).

(c) 2019 H. A. Daniels et al. CBE-Life Sciences Education (๑) 2019 The American Society for Cell Biology. This article is distributed by The American Society for Cell Biology under license from the author(s). It is available to the public under an Attribution-Noncommercial-Share Alike 3.0 Unported Creative Commons License (http://creativecommons.org/licenses/ by-nc-sa/3.0)

"ASCB®" and "The American Society for Cell Biology $\circledR^{\prime \prime}$ are registered trademarks of The American Society for Cell Biology. 
As a first step in examining relationships in research programs, we conducted a qualitative study of STEM undergraduate students from a Hispanic majority institution (HMI) participating in external summer research programs at nine universities. We explore how men and women experience their social relationships with mentors and peers, with a focus on comfort. Qualitative methods allow for in-depth analysis of the processes involved in establishing relationships that would not be possible with quantitative methods. Summer programs away from students' home institutions, which we examine here, serve as an ideal context in which to examine emerging social relationships in STEM, because students are extracted from their usual social contexts, given assigned mentors and roommates, and immersed in intensive research experiences. We believe that feelings of (dis)comfort are particularly important to study, as feeling uncomfortable or having a sense of incompatibility in STEM fields has been linked to underrepresented students exiting the pipeline (Cole and Espinoza, 2008; Strayhorn, 2012; Jackson et al., 2013; Rainey et al., 2018), which is often referred to as the "leaky pipeline." Conversely, feeling comfortable or having a sense of belonging in STEM fields has been shown to positively influence persistence and academic engagement for underrepresented students (Ostrove and Long, 2007; Rosenthal et al., 2011). Moreover, social comfort is an important factor to consider when assessing the benefits that can be gained through mentoring relationships (Allen et al., 2005).

\section{Women in STEM}

Despite women's increasing achievements in higher education (Conger and Long, 2010), gender is still an important element to consider when studying STEM student success. West and Zimmerman (1987) describe gender as a performance we engage in through our interactions. It is not a biologically fixed trait of an individual, but rather a performance that we accomplish through our interpersonal interactions. Gender, then, can be understood as a daily process wherein people negotiate through culturally and linguistically situated role play what it means to be a woman, a man or to have an identity that lies outside that binary (West and Zimmerman, 1987; Butler, 2011; Linneman, 2013; Shepherd, 2016). In this way, gendered expectations for men and women are produced, such as men being more assertive and aggressive than women and women assuming more submissive and nurturing roles. STEM fields that value independent research and limited engagement with others may not provide an ideal context for feminine performances of gender, while rewarding masculine performances of gender.

Performances of gender may explain some of the divergent levels of overall school success between women and men. Morris (2012) revealed how boys' underachievement relative to girls in high school related to their performances of masculinity. Boys performed what Morris terms "contrived carelessness" to enact a masculinity that fostered academic disengagement, because they viewed being too engaged in academics as effeminate. Conversely, girls performed femininity in a manner that promoted strong academic engagement through talking about academic achievements and using their grades as a way to impress peers and teachers. While teachers perceived the boys to have natural academic abilities, teachers more often pointed to the amount of work that the girls put in to achieve their academic success (Morris, 2012).
Counter to the general trend where women's grade point averages (GPAs) are higher than men's in college (Conger and Long, 2010), the gender difference in achievement between men and women is reversed in STEM, and women lag behind men (Griffith, 2010). Women are significantly less likely than men to declare a STEM major upon entering college (Mau, 2016). Although this is a general trend in STEM fields overall, it should be noted that this does not apply to all fields; in biology, women students are overrepresented. Women are also lost from STEM early in their careers. Scholars have characterized this phenomenon as a "leaky pipeline" (Clark Blickenstaff, 2005; Bevan and Learmonth, 2013; Glass et al., 2013).

The gender gap between men and women in STEM is mirrored among Latinas and Latinos (U.S. Commission on Civil Rights, 2010). Literature specific to Latina/o as is relevant here due to our focus on an HMI. Literature specific to Latina/o students in STEM has mostly focused on precollege factors (e.g., Elliott et al., 1996; Oseguera et al., 2006). At the college level, familial attitudes that promote men's interest in science (Anaya and Cole, 2001; Cole and Espinoza, 2008) and "chilly" male-dominated STEM environments on campuses (Hurtado et al., 2007) are particularly relevant to understanding how discomfort may play a role in Latinas leaving the STEM pipeline in college (Crisp et al., 2009; Chang et al., 2014). Their leaving is not due to a lack of interest in STEM, because Latina/o students are equally as likely to express interest in majoring in STEM compared with white students (Chen, 2009; NSF, 2009).

The gendered nature of the STEM career pipeline is well documented (Clark Blickenstaff, 2005). Science is typified as men's work in symbolic and practical terms (Banchefsky et al., 2016). Men tend to be advantaged through resources gained via informal and formal social networks (Bevan and Learmonth, 2013). Women scientists face subtle gender discrimination in hiring and assessment decisions (Moss-Racusin et al., 2012) and in negative attitudes and snide comments (Hirshfield and Joseph, 2012). Women college students can face discrimination in STEM fields and may feel like they do not belong (Carlone and Johnson, 2007; Ong et al., 2011; Jones et al., 2013). Unwanted sexual advancements and sexual harassment are also problems for women in STEM (Greenfield and Peters, 2002).

The culture of science is highly masculinized (Hurtado et al., 2007; Monroe et al., 2008), valuing characteristics traditionally connected more closely to performances of masculinity, for example, aggressiveness and competitiveness (Sallee, 2011). Even men and women scientists perceive "natural" gender differences in math and science aptitude between men and women (Ecklund et al., 2012), in spite of the fact that men and women have equivalent academic and math abilities (Shapiro and Sax, 2011). This presents a difficult situation for women scientists to navigate, as they often feel pressure to perform masculinity to be successful (Rhoton, 2011), but also run the risk of being penalized for engaging in masculine performances (Bevan and Learmonth, 2013; Hirshfield, 2015). Women also face pressure to adhere to strict definitions of (female) masculinity (e.g., by being hypercompetitive), and they are afforded less flexibility in their behavior than men, whose sense of belonging in science seems to permit a wider and more complex array of gendered behaviors (Hirshfield, 2015). Women who feel excluded by the 
prevailing masculine ethos of science (Cech et al., 2011), which systematically devalues women scientists' work (Rhoton, 2011; Bevan and Learmonth, 2013; Knobloch-Westerwick et al., 2013), may conclude they are not well-suited for STEM careers.

Using a qualitative approach, Rainey et al. (2018) emphasized the importance of sense of belonging and comfort as reasons why women persist in STEM majors. They found that women who dropped their STEM majors did not feel they belonged, whereas women who remained in their STEM majors articulated their feelings of comfort. Among STEM students, men and white students consistently rate their sense of belonging in college higher than women and students of color (Johnson, 2012). But, in STEM fields with gender parity such as biology, women report a greater sense of comfort and belonging than women in STEM fields where women are underrepresented (Rainey et al., 2018).

\section{Social Relationships in STEM Research}

Having strong social relationships with faculty and other students is important to student success in higher education and in STEM fields (Hurtado et al., 2007; Cole and Espinoza, 2008; Kuh et al., 2010; McCabe, 2016). Students participating in undergraduate research programs have opportunities to form beneficial social relationships with their faculty mentors, their graduate student and postdoctoral mentors (as applicable), and their peers.

Faculty research mentors are important points of contact for STEM students engaged in structured research programs (Strayhorn, 2010; Ovink and Veazey, 2011; Stolle-McAllister, 2011). Faculty can provide psychosocial mentoring in the form of guidance when students' anxieties heighten and can cultivate informal friendships with students that facilitate the sharing of valuable information, for example, information about scholarships, tips on how to succeed in college, advice for how to deal with difficult professors, or reflections on their own experiences as undergraduates (Nora and Crisp, 2007; Crisp and Cruz, 2009; Dolan and Johnson, 2010). This sort of psychosocial mentoring has positive effects on students (Paglis et al., 2006; Dolan and Johnson, 2009; Thiry and Laursen, 2011), and for women specifically (Dawson et al., 2015). Faculty mentors from similar backgrounds may be particularly important to women students and students of color (Zirkel, 2002; Lockwood, 2006; Feeney and Bozeman, 2008; Stout et al., 2011; Syed et al., 2011; Morales et al., 2018). Others believe there are significant advantages for women and racial/ethnic minority students to be mentored by white men, because such mentees presumably benefit from their mentors' access to power and sponsorship within STEM research fields (Dreher and Cox, 1996; Sosik and Godshalk, 2005). In one of the only studies to examine studentfaculty interactions in undergraduate research, researchers found that women students interacted less frequently with faculty mentors than men, but that URM students interacted as frequently with faculty mentors as non-URM students; unfortunately, the authors did not consider the intersection of race and gender by examining URM women separate from URM men (Aikens et al., 2017).

Graduate students and postdoctoral personnel (called "postgraduate mentors" henceforth) often take on the most prominent roles in mentoring undergraduate researchers (Gonzalez, 2001; Dooley et al., 2004), because they may interact with undergraduate research trainees more frequently than formally assigned faculty research mentors (Thiry and Laursen, 2011; Feldman et al., 2013; Linn et al., 2015; Burgin and Sadler, 2016). They often provide lines of communication between undergraduate research trainees and faculty research mentors and help students acquire technical and conceptual skills while contributing to their professional development (Dolan and Johnson, 2009, 2010; Aikens et al., 2016). In one study, students reported a sense of comfort and relatability with their postgraduate mentors that enabled them to cultivate more productive relationships with their faculty mentors (Dolan and Johnson, 2010).

Peers are also important players in summer undergraduate research programs. Hurtado and colleagues (2009) examined four different institutions with academic and summer structured research programs and revealed that the peer networks created by Latina/o students aided them in completing the programs. However, Johnson and Bozeman (2012) pointed out that, when students associate only with students like themselves in undergraduate research programs, they limit their access to potentially important information. Outside the literature on undergraduate research, recent work has also problematized a one-dimensional (i.e., uniformly positive) view of peer relationships. McCabe (2016) observed that students' peer relationships can be harmful, as when peers who lack similar educational aspirations may drag high-achieving students' academic performances down.

On the basis of the extant literature, we know very little about social relationships that are specific to mentored undergraduate research experiences, especially in terms of distinctions between men's and women's experiences as they go about establishing social relationships with faculty mentors, postgraduate mentors, and peers. Participating in external summer research training programs can be important for undergraduate scientists' development. In these programs, students are given opportunities to build relationships with mentors in authentic research training environments and with their peers through co-residence and collaborative research experiences. They are particularly valuable for URM students, giving these students the opportunity to gain valuable skills for their future careers that may be less accessible during the academic year at their home institutions (Hurtado et al., 2009; Hunter et al., 2007; Harsh et al., 2012). Therefore, studying students during these summer programs provides a window into what makes students thrive in their relationships with others. The following research question is addressed in this study: How do men and women differ in terms of their establishment of summer social relationships with mentors and peers?

\section{METHODS}

\section{The EXCEL Program}

The 17 students participating in this study all receive annual scholarships via the EXCEL research training program and are undergraduate students at the HMI under study. "EXCEL" is a pseudonym used to protect confidentiality of participants. The students' home institution is a national leader in contributing to diversity in higher education, specifically through providing educational opportunities for the rapidly increasing although socially and economically disadvantaged U.S. Hispanic population. The participating students did their first year 
of EXCEL-funded summer research away from their home institution during the study period. None had conducted external research before, and the participants were relatively early in their undergraduate college careers.

EXCEL is a federally funded program designed to train the next generation of researchers from backgrounds traditionally underrepresented in STEM fields. A significant element of the EXCEL program is the arrangement of faculty-mentored summer research experiences. EXCEL students are required to participate in a 10-week mentored summer research program (SRP), coordinated across multiple research partner institutions and their home institution. Approximately two-thirds of students in the program attend one of these partner institutions each summer, while one-third of students remain at their home institution for their summer research experiences. To be eligible for an external summer research experience, each student must maintain a cumulative GPA of $\geq 3.3$. Because the numbers of slots was limited, senior students (e.g., third-year students) had a greater chance of going than junior students (e.g., first-year students). Students who were selected to leave their home institution were matched with their external research mentor based on research interests and discipline/ major. The scholarship program pays the students a modest monthly stipend and covers their food, lodging, and travel expenses while they are away.

\section{Data Collection and Analysis}

We chose to use a qualitative approach to illuminate mechanisms that are not accessible via quantitative methodology (Small, 2009). We conducted semistructured interviews with a set of students to explore their experiences before, during, and after their summer research placements; the protocol was institutional review board approved. Because we had 17 participants, we were able to engage deeply with them over three separate interviews at three points in time. The value of a small- $N$ case study like this is that it allows for deep examination of student experiences in real-life contexts, providing a rich basis for generating new knowledge (Gouvea, 2017). We were guided in our data collection by the principles of grounded theory, whereby researchers enter the field without concrete expectations as to what they will discover (Corbin and Strauss, 2014). Not until we began analyzing the data did gender and relationships emerge as a theme we should explore closely.

The first author (H.A.D.) conducted all of the interviews using the same interview guides, with all questions being asked by H.A.D. to all participants (see the Supplemental Material). During the baseline interviews only, she was assisted by a Hispanic woman undergraduate student. H.A.D. is a white woman graduate student who is a first-generation college student; she attended the same university as an undergraduate as the interviewees. H.A.D. used additional probing questions during interviews to elicit detailed feedback and clarification from participants. All identifying information has been masked to protect the confidentiality of the students participating in this study. Pseudonyms are used for students and mentors, and only the states of the institutions the students attended for the SRP have been provided. For the faculty-mentor pseudonyms, we use last names starting with "M" to signify a man mentor and last names starting with "W" to signify a woman mentor. Students' majors were also omitted, and only the names of their respective disciplinary area (e.g., engineering) have been provided. Finally, the year in which they attended the SRP has been omitted, although the interviews were conducted recently.

Initial baseline interviews were conducted by H.A.D. and a Hispanic woman undergraduate assistant during a Fall semester when 27 students with 4 years of undergraduate scholarship funding remaining via EXCEL were interviewed. Students were asked to reflect on their experiences in EXCEL up to that point, about their expectations for mentoring in general, their personal backgrounds, how they became interested in science, their understanding and identification as researchers/ scientists, their family expectations and social class standing, their long-term goals, and their fears and challenges in terms of being scholarship students.

During the Spring semester of that same academic year, EXCEL staff matched these 27 students for their summer research experiences either at their home institution or at one of the partner universities. Fourteen students who had 4 years of undergraduate funding under the scholarship program at the baseline interview (11 women and three men) were assigned to summer research experiences outside their home institution, and we selected them for inclusion in this study. These students were first- and second-year students, based on their earned credits at the beginning of this study. To have a diverse set of interviewees, we identified three additional male students, each of whom had 3 years of undergraduate scholarship funding remaining. These students were selected for inclusion based on their acceptance to attend an SRP outside their home institution with one of the other 14 students. On the basis of their earned credits at the beginning of the study, these men were classified as second-year students ( $n=$ 2 ) and a third-year student $(n=1)$. This young man had switched majors and therefore had more years left to degree than his credits indicate. These students were recruited and baseline interviewed at the end of that Spring semester, creating a set of 17 students. They had majors in the physical and life sciences, engineering, behavioral sciences, or health sciences, and all EXCEL students have a biomedical science focus in their course work and research. None had conducted research through an external summer program before the summer highlighted here. Reflective of the institution's HMI status is the fact that 15 of these 17 students identified as Hispanic, Mexican, or Mexican American. Students used these terms to refer to themselves during the interviews, which is reflective of language patterns along the U.S.-Mexico border, where those terms are more commonly used instead of "Latina/o" or "LatinX." For that reason, we use the term "Hispanic" when referring to our participants.

Demographic information about each student is included in Table 1.

H.A.D. interviewed the 17 students over the phone halfway through their SRPs and face-to-face within 2 weeks of return from their SRPs. Within these two interviews, she asked each student background questions about their expectations for mentoring, their understanding and identification as a researcher and scientist, their family expectations and background, their long-term goals, and their fears and challenges in terms of being scholarship students. Specific to 
TABLE 1. Demographic information and research team structure for each interviewee

\begin{tabular}{|c|c|c|c|c|c|c|c|c|}
\hline Pseudonym & $\begin{array}{c}\text { Disciplinary } \\
\text { area }\end{array}$ & Classification & $\begin{array}{c}\text { Race/ } \\
\text { ethnicity }\end{array}$ & Sex & Parents' income $^{a}$ & $\begin{array}{c}\text { First-generation } \\
\text { college } \\
\text { student }{ }^{\mathrm{a}, \mathrm{b}}\end{array}$ & $\begin{array}{l}\text { Gender of the } \\
\text { student's PI } \\
\text { (faculty } \\
\text { mentor) }\end{array}$ & $\begin{array}{l}\text { Role(s) and } \\
\text { gender(s) of } \\
\text { the student's } \\
\text { postgraduate } \\
\text { mentor(s) }\end{array}$ \\
\hline Victoria & $\begin{array}{l}\text { Physical or life } \\
\text { sciences }\end{array}$ & Second year & Hispanic & $\mathrm{F}$ & $\$ 10,000-\$ 14,999$ & No & Woman & $\begin{array}{l}\text { Graduate student } \\
\text { (woman) }\end{array}$ \\
\hline Alma & $\begin{array}{l}\text { Behavioral } \\
\text { sciences }\end{array}$ & First year & Hispanic & $\mathrm{F}$ & $\$ 10,000-\$ 14,999$ & No & Man & $\begin{array}{l}\text { Graduate student } \\
\text { (man) }\end{array}$ \\
\hline Salvador & Engineering & First year & Hispanic & M & $\mathrm{N} / \mathrm{K}$ & $\mathrm{N} / \mathrm{K}$ & Man & $\begin{array}{l}\text { Graduate student } \\
\text { (man) }\end{array}$ \\
\hline Antonio & $\begin{array}{l}\text { Behavioral } \\
\text { sciences }\end{array}$ & First year & Hispanic & M & $\$ 150,00-\$ 199,999$ & No & Woman & $\begin{array}{l}\text { Graduate student } \\
\text { (woman) }\end{array}$ \\
\hline Sofia & $\begin{array}{l}\text { Physical or life } \\
\text { sciences }\end{array}$ & First year & Hispanic & $\mathrm{F}$ & $\$ 75,000-\$ 99,999$ & Yes & Woman & $\begin{array}{l}\text { Graduate student } \\
\text { (man) }\end{array}$ \\
\hline Elena & $\begin{array}{l}\text { Physical or life } \\
\text { sciences }\end{array}$ & First year & Hispanic & $\mathrm{F}$ & $\$ 100,00-\$ 149,999$ & No & Man & $\begin{array}{l}\text { Research staff } \\
\text { (woman) }\end{array}$ \\
\hline Ivan & $\begin{array}{l}\text { Physical or life } \\
\text { sciences }\end{array}$ & First year & White & M & $\mathrm{N} / \mathrm{K}$ & $\mathrm{N} / \mathrm{K}$ & Man & $\begin{array}{l}\text { Graduate student } \\
\text { (man) }\end{array}$ \\
\hline Jasmine & $\begin{array}{l}\text { Health } \\
\quad \text { sciences }\end{array}$ & Second year & Other & $\mathrm{F}$ & $\$ 15,000-\$ 19,999$ & No & Man & $\begin{array}{l}\text { Graduate student } \\
\text { (man) }\end{array}$ \\
\hline Luciana & $\begin{array}{l}\text { Physical or life } \\
\text { sciences }\end{array}$ & Second year & Hispanic & $\mathrm{F}$ & $\$ 75,000-\$ 99,999$ & Yes & Woman & $\begin{array}{l}\text { Graduate student } \\
\text { (man) }\end{array}$ \\
\hline Daniela & $\begin{array}{l}\text { Physical or life } \\
\text { sciences }\end{array}$ & First year & Hispanic & $\mathrm{F}$ & $\$ 40,000-\$ 49,999$ & No & Woman & $\begin{array}{l}\text { Graduate student } \\
\text { (man) }\end{array}$ \\
\hline Isabel & Engineering & First year & Hispanic & $\mathrm{F}$ & $\$ 30,000-\$ 39,999$ & No & Woman & $\begin{array}{l}\text { Graduate students } \\
\text { (woman) }\end{array}$ \\
\hline Adrian & Engineering & Second year & Hispanic & M & $\$ 75,000-\$ 99,999$ & No & Woman & $\begin{array}{l}\text { Graduate students } \\
\text { (woman) }\end{array}$ \\
\hline Marcos & Engineering & Second year & Hispanic & M & $\$ 20,000-\$ 24,999$ & No & Man & $\begin{array}{l}\text { Lab coordinator } \\
\text { (woman) }\end{array}$ \\
\hline Michelle & Engineering & First year & Hispanic & $\mathrm{F}$ & $\$ 50,000-\$ 59,999$ & No & Man & Postdoc (woman) \\
\hline Mariana & $\begin{array}{l}\text { Physical or life } \\
\text { sciences }\end{array}$ & First year & Hispanic & $\mathrm{F}$ & $\$ 10,000-\$ 14,999$ & No & Woman & $\begin{array}{l}\text { Graduate student } \\
\text { (woman) }\end{array}$ \\
\hline Jackie & $\begin{array}{l}\text { Physical or life } \\
\text { sciences }\end{array}$ & First year & Hispanic & $\mathrm{F}$ & $\$ 40,000-\$ 49,999$ & No & Woman & $\begin{array}{l}\text { Graduate student } \\
\text { (man) }\end{array}$ \\
\hline Elias & $\begin{array}{l}\text { Physical or life } \\
\text { sciences }\end{array}$ & Third year & Hispanic & M & $\mathrm{N} / \mathrm{K}$ & $\mathrm{N} / \mathrm{K}$ & Woman & $\begin{array}{l}\text { Graduate student } \\
\text { (man) }\end{array}$ \\
\hline
\end{tabular}

${ }^{\mathrm{a}} \mathrm{N} / \mathrm{K}$, not known.

bFirst-generation college student: One or both parents does not have bachelor's degree or higher.

their SRP experiences, H.A.D. asked students to discuss the research they were engaged in and the skills they were gaining; to reflect on their relationships with their mentors and other individuals in their labs (graduate students, postdocs, undergraduate students) and to talk about the connections they were making with others inside and outside their research settings; to assess any changes in their identification as a scientist relative to their baseline interviews; and to report on challenges they encountered (or were encountering) during their summer experiences and how they dealt with them.

Overall, we collected more than 72 hours of interview data from these 17 students, with each interview lasting anywhere from 30 minutes to 3 hours, with an overall average of 1 hour and 30 minutes. We noted that the interview conducted while the student was away was usually longer than the first and third interviews, reflecting the students' desire to talk through their experiences while they were happening. With interviews taking place as their experiences were unfolding, students provided rich descriptions of their lab environments and the relationships they were forming with faculty research mentors, postgraduate mentors, and peers. During the course of the project, some students began to identify with H.A.D. as a confidant. At the conclusion of the study, some students said they felt as though they revealed information to H.A.D. that they had not shared with others. These rich descriptions from unique students are the strength of our qualitative approach, as opposed to the strength of a quantitative approach emphasizing generalizability (Small, 2009).

Each interview was transcribed by H.A.D. and analyzed using NVivo 11 qualitative analysis software. Our analysis was guided by grounded theory, beginning with open coding to help us "break into the data" and make sense of the information gathered (Corbin and Strauss, 2014, p. 239). We created broad, thematic codes based on the content of the interviews regarding social relationships cultivated through the SRP and the 
extant literature. We developed these thematic codes using an issue-focused analysis (Weiss, 1995). Initially, we created nine categories to explore the relationships students were forming during their SRPs. The initial categories captured excerpts of the interviews concerned with the following: faculty mentors (in general), family, officially assigned faculty research mentors, peers (not in the lab), graduate students, postdocs, program resources that shape social relationships, research staff (not faculty), and undergraduate students in the lab. During weekly research meetings, the authors and other research team members discussed thematic codes and quotations. The team comes from different ethnic, gender, and socioeconomic backgrounds and have varying levels of involvement with EXCEL. These different perspectives offered competing interpretations at times, which led to discussions and ultimately strengthened our findings. Following Weiss (1995), our discussions of thematic codes and quotations involved summarizing the excerpt files created for all students and ideas about how these statements would fit into the created categories. We narrowed the focus of these categories to explore relationships and collapsed these nine categories into three broad categories: relationships with official faculty research mentors, secondary postgraduate mentors, and peers.

Upon completion of the coding, we conducted matrix queries of these three categories (using NVivo) to aid our analysis of differences between men and women students. After many iterations of reading and discussing thematic coding, the general theme of "comfort in relationships" emerged and was discussed at weekly research team meetings. Under that broad heading, we focused this paper on students' comfort related to: lack of guidance from mentors, psychosocial mentoring (e.g., friendship and guidance when students' anxieties emerge), having a same-gender mentor, engaging in informal interactions with mentors, and peer networks.

\section{Research and Mentoring Context}

All students had a formally assigned faculty research mentor, who was the lead professor (usually called "the PI" by the student) within the research training environment. Once they arrived for their summer research experiences, the majority of students had frequent contact with their faculty mentors: 13 of 17 students reported meeting with their mentors at least weekly (e.g., at regularly scheduled lab meetings or one-on-one). Interviewed students worked in different research settings ranging from small teams of only two to three people to larger teams that worked in partnership with other teams where 10 or more people would be available for students to work with on any given day. The majority of students $(n=11)$ reported that graduate students were the individuals they worked with on a daily basis, although four students also worked with postdoctoral personnel. About half of the students $(n=8)$ reported working with other undergraduate students in their summer research environments. While this number may seem low, the students were matched individually with faculty. They were not matched with mentors in groups. In some of the SRP locations, there were few undergraduates doing summer research, and so faculty had limited opportunities to have more than one student on their teams. Even when there were many undergraduate students doing research in a particular SRP location over the summer, many faculty mentors accepted only one undergraduate for the summer. Students who participate in external SRPs are often housed in dormitories with other visiting students who are participating in the same program or another program at the same university. In this study, 14 out of the 17 interviewed were housed with other undergraduates in dormitories or extended-stay hotels.

\section{RESULTS}

To preview our results, women and men discussed differences in terms of how comfortable they were with independence in their new research environments. Women placed greater value on mentoring that involved a level of friendship and counseling compared with the men in our study. Same-gender mentoring was valued more by women than men in the study. Men and women discussed different levels of comfort in engaging in informal interactions with official faculty research mentors. Men were more comfortable engaging in informal interactions with faculty and postgraduate mentors, and with broad peer networks. It is likely that differences in the level of comfort in various social relationships could ultimately contribute to the underrepresentation of women in STEM fields, although that endpoint is beyond the scope of this study.

\section{Guidance from Mentors}

Women and men expressed different levels of comfort in relationships with faculty mentors that were characterized by a lack of clear guidance related to their research tasks. The women reported varying levels of discomfort with relationships in which they were expected to work independently from their mentors. They reported asking many more questions than men and expressed more self-doubt about their autonomy within their research training environments and the tasks they were required to complete. This is evidenced by Michelle, who said, "So I would be scared of like blowing up something or messing something up. So sometimes I felt like I was left alone too many times because I don't know." Michelle continued to explain how she would reach out to other individuals in the lab for help directly because of these fears. Other women directly approached their faculty mentors to request more guidance. For example, Luciana discussed how she handled questions about her assigned tasks: "So whenever I'm not clear about what she wants me to do, I just go up to her before starting and I ask for approval of what I'm going to do, what I'm going to use, and everything."

On the other hand, the six men interviewees expressed comfort in relationships with their faculty mentors that were characterized by more independence in the lab and expressed a reluctance to reach out to their faculty research mentors when issues or questions arose. Men like Salvador reported being empowered by the process of trying to resolve issues on his own. Salvador explained,

The best part about doing research is, I guess, the independence. Independence because you get to ... I mean, my [postgraduate] mentor was there. I could have asked him anytime, like "Hey I need help with this." And I did. But I would try to figure out things by myself and just do the experiments on my own and kind of like get to understand what's going on and how to proceed. Like, what's the next step after I get my results? I think that was the best experience because I got to 
work independently—kind of like critical thinking—on my experiment.

When asked whether he felt prepared for the summer research experience during the midpoint interview, Adrian explained that he was actively learning and felt confident in his capabilities to complete any task given to him by his mentor without much guidance. He said,

Yes, I do feel like I have enough background knowledge and skills to be able to carry on any project that my mentors would give me and if it happened to be ... I've been learning how to work with the [computer] program, I'm still learning. But yeah, I mean I feel pretty confident about the project I'll be working on and whatever else it is that I might need to say in the future.

Similar to Salvador, Adrian projected an image of confidence in his abilities and comfort in the lab.

\section{Psychosocial Mentoring}

Psychosocial mentoring occurs when mentors establish close relationships with students that go beyond providing career guidance and technical skill training. Students often interpret psychosocial mentoring as a form of friendship wherein mentors provide guidance on issues outside academics and lab work, but they retain an understanding that the relationship is still primarily a professional connection (Crisp and Cruz, 2009; Dolan and Johnson, 2010). The women interviewees conveyed their desire to receive psychosocial support from their mentors, and they felt more comfortable when this form of mentoring was provided. As women, they were also likely to be offered this type of mentoring without solicitation. Graduate student mentors tended to provide psychosocial mentoring to women students. For example, when Sofia was asked to rate her graduate student mentor in terms of the psychological and emotional support she received, she rated him a 10 on a 10-point scale and said,

That definitely makes me feel like I have a lot of support. I do feel like I can come to him with ideas and come to him with propositions like, "Oh I think maybe we should go in this direction" or "Maybe I'd like to change this about the thing that I made." .... I feel like I feel safe enough to propose it and I feel that whatever I say, it will be taken into deep considerationlike genuine consideration.

Sofia interpreted her graduate student mentor's respect for her ideas about the research in emotionally supportive terms. She, like other women interviewees, felt comfortable with her postgraduate mentor, which allowed her to form a close relationship with him. Furthermore, women often talked about reaching out to their postgraduate mentors if they felt lonely or homesick while away from their home institutions; in contrast, men interviewees did not report doing this. Luciana, for example, stated the following about her postgraduate mentor: "So he's real accessible ... He tells me a lot about how he deals with being away from home. 'Cause I'm in [program X] and he was also in [program X] like 2 years ago. So he knows what I'm going through." Michelle also discussed the emotional support provided by her postdoctoral mentor. In addition to helping her learn requisite technical skills, her postdoctoral mentor became someone she could confide in about being lonely due to being away from home. This was an experience that they shared, being that her postdoctoral mentor was an immigrant to the United States whose family lived overseas. Although numbers are too small to draw definitive conclusions, Salvador had a postgraduate mentor who was an immigrant and person of color, but these features were not discussed in positive terms during our interviews with him.

The men whom we interviewed did not seem to value the psychological/emotional aspects of mentorship, with the exception of Antonio, who showed an appreciation for the emotional support provided by his women faculty and postgraduate mentors. When asked how he would rate his woman faculty mentor in terms of psychological and emotional support, he said, "Psychological support? I've never thought of that. I guess psychologically, she really is supportive. 9/10, I guess. Because she really does ask me how I've been doing. How am I doing in the dorms? Do I feel overwhelmed? Do I feel bored? Is this enough? Do I want more?" The other men expressed some discomfort when asked to rate their mentor in this area and provided few concrete examples of the support they received in comparison to examples given by women. Even Antonio did not provide details comparable to the women about this aspect of mentorship, and he had not thought about this aspect of her mentorship until prompted during the interview. This lack of interest in talking about emotional support may be part of a broader gendered performance, wherein men actively cultivate confident and independent personae in STEM.

When Salvador was asked to rate his postgraduate mentor in terms of psychological and emotional support, he stated, "I would give him a 4. Just because he doesn't speak up a lot and he doesn't seem to have authority. So I don't know if he was like bullied before, like when he was back in [his home country], in elementary school or middle school. He doesn't have great self-esteem." Salvador unfavorably assessed his postgraduate mentor due to his perception that his mentor was not confident in himself, which may have translated to an inadequate performance of masculinity.

\section{Same-Gender Mentors}

Gender concordance between women students and their women mentors seemed to influence students' level of comfort with their mentors as well as the mentoring they received. Table 2 presents the different categories of mentoring concordance present in this study. While the numbers in each group are small, our analysis of the qualitative data suggests that women established strong relationships with their women faculty mentors $(n=7)$, while women paired with men faculty mentors ( $n$ $=4$ ) did not make very strong connections. Men paired with women faculty $(n=3)$ and men paired with men faculty $(n=3)$ also did not report the same level of comfort as women with women. At the level of the postgraduate mentor, gender concordance appeared to be less important; as illustrated above, women spoke favorably about very supportive relationships with men postgraduate mentors (e.g., Luciana, Sofia).

As an example of the closeness between women faculty mentors and women mentees, we will highlight Victoria and Dr. Walter. Dr. Walter oversaw a small research team, and Victoria 
TABLE 2. Gender concordance between students and their faculty and postgraduate mentors ( $n=17$ students)

\begin{tabular}{lcc}
\hline Gender concordance categories & Men students & Women students \\
\hline Gender-matched faculty mentor, gender-unmatched postgraduate mentor & 1 & 5 \\
Gender-matched faculty mentor, gender-matched postgraduate mentor & 2 & 2 \\
Gender-matched faculty mentor, no postgraduate mentor & 0 & 0 \\
Gender-unmatched faculty mentor, gender-matched postgraduate mentor & 1 & 2 \\
Gender-unmatched faculty mentor, gender-unmatched postgraduate mentor & 2 & 1 \\
Gender-unmatched faculty mentor, no postgraduate mentor & 0 & 1 \\
\hline
\end{tabular}

reported daily face-to-face communication with her woman faculty mentor and time spent developing hands-on research skills. Victoria and Dr. Walter were able to discuss her academic and career goals in depth because of the close relationship they shared. This led Dr. Walter to devise a strategy for how Victoria could network at a nearby university that has a particularly strong graduate program in Victoria's area of interest. Victoria explained, "So she told me that I could contact them. That she would help me write emails. And once all the faculty replied to me, then we could arrange to go and visit them so I could talk to them personally and she would go with me. Like she would take me to [city] and she would stay with me to support me with talking to the faculty and everything." This psychosocial support was significant and valuable for Victoria who is a low-income minority woman in STEM. This day trip allowed Victoria to meet graduate school contacts at another university. The time Victoria spent with Dr. Walter was very valuable and unique; most of the interviewed students did not report spending this amount of dedicated time with their mentors. Mariana, who discussed meeting her faculty mentor only a handful of times, described the comfort and accessibility she felt: "But she's very, very friendly person in general. She's very easy to trust with so you can talk to her very easily and she's very kind ... She's very willing to help me." Although Mariana did not spend as much dedicated time with her faculty mentor as Sofia was able to, she reported feeling that her woman mentor was approachable and warm.

Not all women we interviewed experienced this level of support from their women faculty mentors. Sofia reported that her woman mentor seemed uninterested in establishing a relationship with her and did not allow her to work on her own project, instead requiring her to shadow a graduate student. When asked whether there were times when she felt she did not belong, Sofia discussed how her mentor told her that she would not be able to work on an independent research project, although Sofia believed she had clearly asserted her willingness and desire to do so. Sofia compared her experience with that of another external undergraduate student visiting the same mentor's lab for the summer: "An individual who's in marketing, who's not interested at all, got his own project doing tissue engineering. I try not to speculate on it too much and I believe everything happens for a reason, but I feel like there was something other than my willingness to do the project that kept me from being assigned my own [project]." This example provides an important counterpoint to Victoria's narrative, revealing that not all women faculty are nurturing and supportive mentors to their women students.

Of the four women paired with men as mentors, none formed particularly close bonds and two (Jasmine and Elena) articulated discomfort with some aspects of their mentoring relationships. The other two (Alma and Michelle) spent very little time with their men faculty mentors (i.e., one to a few visits in total), although Michelle felt honored to have associated with her well-known mentor. Jasmine worked on a regular basis with Dr. Martinez, but did not speak favorably about their relationship. She felt that intellectually they were a mismatch and felt more comfortable seeking guidance from a woman mentor back at her home institution, even during the summer experience. Elena also reported feeling somewhat uncomfortable with her official faculty mentor's hands-off mentoring approach. She spoke during her midpoint and final interviews about a feeling of unease regarding the next step in her research and discussed a desire for her mentor to provide her with more guidelines to accomplish her given tasks.

Gender concordance did not seem to impact the relationships men in this study built with their official faculty research mentors. Three out of the six men were paired with official faculty research mentors who were also men. However, they infrequently interacted with these official faculty research mentors and did not discuss aspects of their relationships such as role modeling or psychosocial support, in contrast to several of the women in the study.

\section{Informal Interactions with Mentors}

Men reported feeling quite comfortable interacting in informal settings, not only with faculty mentors, roommates, and peers, but with a broad range of individuals whom they met during their summer research experiences. Informal interactions, especially with mentors, can be particularly beneficial in helping students feel they are a part of the research community and in opening up new opportunities that are often discussed over coffee or beer. Some women expressed discomfort in interacting socially with men researchers and professors in general. As an extreme case, Jackie discussed how she reached out to a professor at her host institution whom she was interested in meeting because his research expertise aligned with her interests. She explained,

He responded. He said "Oh yeah sure anytime we can go ... You can ask me questions about what I do over a cup of coffee." And when he told me that, I got scared. I was like, "No!" That means I'm gonna have to make a long conversation with him and that's an opportunity for me to be socially awkward. So I've been avoiding that email you know [laughs]. So, yeah, I'm not too comfortable doing that stuff.

When asked later about this incident, Jackie explained that when she sent the email, she imagined visiting the lab and seeing the team at work. When the professor responded with an invitation to meet one-on-one over coffee, she balked, because 
she felt that she did not have enough to say about her research interests. She explained to us that she had just finished her freshman year and was not confident in meeting with a professor in an informal, one-on-one, social context.

When Salvador, who was paired with men faculty and postgraduate mentors, was asked whether he felt comfortable around people of authority at his host institution, he described a sense of comfort due to an early informal interaction at a bar in his summer research experience. He explained, "So I wasn't expecting that, but it happened and I was happy with it. I was chill with it, like, I didn't mind, but I wasn't expecting that, to ever drink with my mentor. So that was something I wasn't expecting." Even though Salvador may have felt some initial discomfort with going to a bar with this faculty mentor, it did not hold him back from participating in the interaction, as was the case for Jackie. While being invited out for drinks with a mentor was uncommon among this group of students (this happened only to Salvador), Salvador's willingness to interact informally was typical of the men in the study.

\section{Breadth of Peer Networks}

The men in the study felt comfortable engaging in a wide variety of social interactions and therefore formed peer networks that were relatively large and diverse. The women maintained relationships with a few individuals with whom they reported close ties, and these were usually other Hispanic women. Women frequently highlighted the value of having peers who could provide interpersonal support and guidance. Women formed meaningful social bonds with their roommates in the dorms, more often than with lab mates. It seems as though the status of EXCEL students as summer interlopers kept them on the outside of in-lab peer networks. Isabel remarked that she did not feel particularly comfortable with her peers in the lab: "There's a group of girls at the lab who have been friends for ... they've probably been working in this lab the whole semester, for years probably, and they're very good friends." Given that many of these summer programs were targeting underrepresented STEM majors, the students' roommates were usually from backgrounds similar to the EXCEL students. Women emphasized how sharing the same aspirations was very important in terms of the relationships they established with their peers in the dorms. For example, when Mariana was asked to reflect on a time where she felt like she belonged during her summer research experience, she discussed the time spent with her peers in the dorms:

Even though we were from different fields, we all had that same purpose in a way for grad school and getting your Ph.D. and you're furthering your education. And that was really ... it was just the place where I was most comfortable, with them, talking about it, you know? Maybe because we spent so much time together, but it was just really comforting to be around there. You just fit.

Students living together for the summer experience formed mutually supportive social relationships that allowed them to share valuable information, build one another's confidence, and provide advice that supported competent interactions with faculty research mentors and other research team members in lab. This appeared to be especially valuable for the women interviewees.
Some men reported wanting to socialize with a wide variety of individuals, not just their roommates in the dorms. As Elias explained, "Yeah, just trying to make friends and long-lasting connections and who you want to connect with. I just focused on that. I think that's the best part of traveling too. Meet new people and then staying in contact with them. I think that was the best part. Also the job, but I think the best part is still the people." Enrique stated he had connected with at least 50 students while away for his summer research experience. He also mentioned that he asked his peers about their research interests upon meeting them, to see what he could learn. Men often discussed the social and strategic benefits for their future careers gained through engaging with individuals from a variety of backgrounds, rather than emphasizing the importance of receiving social support from peers with whom they felt similar, in contrast to what the women expressed.

Men's comfort with interacting broadly was facilitated by their relative lack of concern about safety issues; only one man (Antonio) brought up concerns about crime during the interviews. Conversely, fears about crime and safety may have played a role in the hesitancy of women to interact socially in public spaces with a variety of people. Six out of the 11 women expressed concerns about the safety of their new areas. For example, Daniela stated, "The campus is kind of located next to a street that has a reputation of not being so safe. So, you know we try to avoid that at night." While other women interviewees spoke about their concerns related to crime, we will highlight the case of Sofia, because she and Salvador both lived in on-campus apartments in a small college town while doing summer research, but had very different feelings regarding safety. When asked how he felt his gender shaped his overall summer experience, Salvador stated,

It depends. 'Cause Sofia, she wouldn't like to go out. So she would always ask me like, "Hey you wanna come along?" And as far as me, I guess 'cause I'm a guy, and I don't worry about getting robbed or something, I just go alone. If I need to go downtown, I just go and come back. I don't have to ask someone to come with me. So I guess I have in a way more independence, 'cause I could go do whatever I want. I don't run any risk of getting harmed or something for being a girl.

Salvador tapped into some women's relative discomfort with engaging in informal interactions in public spaces due to fears about crime. Sofia echoed these concerns about being alone in a new space during the interview we conducted with her while she was away and recognized that Salvador felt more comfortable than she did. She stated, "I just didn't feel safe in my apartment for a while. I was like, 'I'm going to ask Salvador if he'll let me sleep in his bathtub ...' I feel like, oh my God, like what the heck. Like what if there is somebody hiding in the cabinets, I had to check all the cabinets." She continued,

And my professor when he drove us into [town], he made us stop at his house and he leaves the door to his house unlocked and I think that is the craziest thing. And even Salvador, he started doing the same thing! And I'm the complete opposite. I have to lock my doors and lock my windows. And before I go to sleep ... I have to make sure the doors are locked. I put a chair at the door. I have to check the windows before I can sleep comfortably. 
In contrast to Salvador, Sofia did not feel entirely safe while away at the SRP, and this influenced her level of comfort in going out and meeting new people, ultimately restricting her to establishing relationships with other students.

\section{DISCUSSION}

Women and men felt comfortable establishing different sorts of social relationships during their STEM SRPs, and this may have benefited them in different ways. Women interviewees expressed comfort in relationships with mentors who provided psychosocial mentoring, were available and approachable to answer questions, and were of the same gender, and with peers who had similar backgrounds. Men interviewees conveyed comfort (or, at the very least, expressed more comfort than the women participants) in relationships with mentors who offered little guidance, provided little psychosocial mentoring, and engaged with them informally; they were also comfortable cultivating relationships with a wide variety of peers. This section will connect these findings to ideas about gender performances and explore how the findings might be useful for efforts to encourage URM women to continue their pursuit of STEM careers.

Elements of stereotypical gender performances seemed to play into the differences in comfort we observed. Men interviewees more frequently seemed to project masculine images of comfort and capability as they described themselves within their research environments. This confidence resulted in them asking few questions, while women often discussed asking questions as they worked. We wonder whether men's hesitancy to ask questions and instead resolve issues independently may prime them for success within the STEM research environment. This raises the open question as to whether STEM faculty mentors (especially men) may preferentially respond to this type of gendered performance compared with those of women, who described being more hesitant and less self-assured in the lab. While this is beyond the scope of our paper, we believe it warrants additional consideration in future work.

The openness that women displayed to psychosocial mentoring was not mirrored by the men and reflects a more stereotypical feminine gender performance. Multiple women reported that their postgraduate mentors were important sources of social support, something described by none of the men. In contrast, a male student dismissed his postgraduate mentor in unfavorable terms due to a perceived lack of self-esteem; this may reflect the student's embrace of the values of confidence and competitiveness, which are integral to the prevailing masculine culture of STEM (Hurtado et al., 2007; Monroe et al., 2008; Sallee, 2011; Ecklund et al., 2012). In general, men interviewees exhibited a propensity to overlook the potential benefits of psychosocially supportive relationships. The devaluation of psychosocial support, combined with comfort with loose-knit mentoring relationships characterized by little guidance, reflects the level of comfort that even these novice men scientists felt in research settings.

Women interviewees expressed a greater degree of comfort with women than men faculty mentors due to shared relational styles, perceived warmth, and approachability. In a quantitative study examining these same students and their EXCEL peers, findings showed that women students had greater self-reported gains at the end of the SRP when they were paired with same-gender faculty mentors than did men students (Morales et al., 2018). Others have highlighted the importance of same-gender mentors for women, because the women mentors can be role models to their students (Lockwood, 2006) and tend to provide psychosocial mentoring to their women mentees (Allen et al., 2005). We also found those aspects of same-gender mentoring to be important for women.

We speculate that gender concordance might act as a buffer to help keep women from dropping out of STEM, because women faculty mentors may not view women mentees' gendered behaviors as indicative of disinterest or incompetence and may even reward feminine performances. Women mentors may understand and relate to their women mentees' behavior differently than men mentors. Previous studies exploring the gender gap between men and women in STEM have explored the male-dominated climate of STEM as a factor in Latina students leaving the STEM pipeline (Hurtado et al., 2007). Our findings suggest the hypothesis that gender concordance between women mentors and their Hispanic women mentees may help to counteract the tendency for masculine behaviors in STEM environments to be rewarded, which needs to be examined via future studies involving analysis of data collected from both mentees and mentors.

Men and women students in this study seemed differentially comfortable with informal interactions with mentors. Previous studies indicate that men are more frequently invited to engage in informal interactions in STEM and in organizations more generally, and it is in these spaces that opportunities for advancement and networking are often created (Thompson, 2001; Bevan and Learmonth, 2013). While this may not have been the case for the women students in this study, the literature demonstrates that women may hesitate to meet informally or work closely with men, and may even leave STEM career pathways, due to fears about unwanted sexual advances, sexual harassment, and negative judgments about being alone with men outside work (Greenfield and Peters, 2002). Additionally, in some informal contexts related to work (e.g., an informal lunch with lab members), women may find themselves to be the only woman present. The topics of conversation in these settings may shift such that women feel less comfortable participating. Given the gendered expectations in some Hispanic families, Hispanic women college students may be even less likely to interact comfortably with strangers during their summer research placements than white women, making the ream of informal interactions an even more important site of exclusion for them. Familial expectations for Latinas can inhibit their independence and factor into their decisions during college, while Latino men have reported a sense of independence from familial expectations in college (Desmond and López Turley, 2009; Ovink, 2014). These expectations may also have contributed to women in this study avoiding broadly socializing and instead focusing on their research.

Related to peer relationships, men and women strongly diverged in terms of their social comfort zones: men sought out weak ties with a variety of people, and women formed fewer strong ties with women who were similar to themselves. Each approach seemed to yield different benefits. Men's approach allowed them to tap into the informational benefits of diverse peer networks (Johnson and Bozeman, 2012). As these men interacted socially with a variety of people in new places during 
the summer, it seems as though these behaviors might be preparing them for successful transitions to graduate school, when most will again move to new communities away from their home city and co-ethnic peers. The women participants may not be similarly advantaged. They expressed more fears about crime and safety. And, as Johnson and Bozeman (2012) highlighted, a pitfall of URM students' confining their networks to students similar to themselves is the lack of access to resources and information that can be passed along from more privileged peers. There is also a positive flip side of these more restricted networks for Hispanic women and women in general: the creation of safe spaces. These safe spaces may help these young women feel supported, providing a place where resources and information can be shared openly. The importance of safe spaces where women can speak freely with supportive peers is well documented (Collins, 2000).

\section{LIMITATIONS}

Several limitations pertain to this study. The study would have benefited from having more men and an equal number of men and women participants. Three of our men also had more college credits than the other participants, although none had done summer research before. An equal number of students of each gender would have given us a richer data set and enabled better comparisons. Also, we have limited information on the students' previous research experiences and how the mentors viewed the students, because we focused on students' perspectives. Future research would benefit from conducting brief phone or email interviews with faculty research mentors to gauge their perceptions of their students' performances and their opinions on their established relationships during the summer experience. While one strength of the study is multiple interviews with each student, an additional follow-up interview 6 to 12 months later would be useful to see how students' relationships developed or fizzled after their summer experiences. We were also unable to capture a wide range of gendered performances. For example, a previous study found that some women in physics do not identify with traditional femininity and feel that they fit into the discipline well because of this (Danielsson, 2012). Exceptions to typical gender performances, such as women behaving in masculine ways (e.g., women being competitive and verbally assertive) and men performing in a typically feminine manner (e.g., men being cooperative and nurturing) exist, but were not well represented in our set of interviewees. It may have been that the Hispanic students in this study engaged in more traditional gender performances than would have been found in a more diverse set of students. This study is focused on Hispanic students' experiences engaging in a funded undergraduate research program. Therefore, these results should not be generalized to all students participating in undergraduate research. By focusing on a larger and more diverse set of students, future research could better capture a full range of gendered performances applicable to relationship building in STEM. Finally, H.A.D. coded the data, and we did not assess interrater reliability. Future research would benefit from multiple coders and assessing interrater reliability.

\section{CONCLUSION}

Our results suggest that there are gender differences in how early undergraduate STEM students who are primarily Hispanic establish and experience social relationships during this specific summer research experience away from their home universities. Examining students' perspectives on social relationships formed during a summer while conducting mentored research helps illuminate factors that may potentially contribute to Hispanic women leaving STEM fields later in their college careers. In spite of smaller numbers of men interviewees, the differences between how men and women understood and described their relationships were striking, and this reflected how comfortable men were in the masculine setting of STEM research (Hurtado et al., 2007; Monroe et al., 2008). Men felt more at ease in loose-knit mentoring relationships characterized by little guidance and an absence of psychosocial mentoring. They also expressed comfort in engaging in informal interactions with a wide variety of people. While some women felt comfortable with their mentoring relationships and informal social interactions, it was more common for women to express some level of discomfort. Women's discomfort in STEM is a documented reason for why they leave the pipeline (Greenfield and Peters, 2002; Crisp et al., 2009; Chang et al., 2014). As such, we need to alter STEM research environments so that they do not actively repel women. Until that happens, being paired with women faculty mentors and cultivating close relationships with women peers from similar backgrounds may help women, and Hispanic women in particular, mitigate some of the repelling effects of gendered STEM research experiences.

\section{ACKNOWLEDGMENTS}

Research reported in this article was supported by the U.S. National Institute of General Medical Sciences of the National Institutes of Health (NIH) under linked award numbers RL5GM118969, TL4GM118971, and UL1GM118970. The content is solely the responsibility of the authors and does not necessarily reflect the views of the National Institutes of Health.

\section{REFERENCES}

Aikens, M. L., Robertson, M. M., Sadselia, S., Watkins, K., Evans, M., Runyon, C. R., ... Dolan, E. L. (2017). Race and gender differences in undergraduate research mentoring structures and research outcomes. CBE-Life Sciences Education, 16(2), ar34.

Aikens, M. L., Sadselia, S., Watkins, K., Evans, M., Eby, L. T., \& Dolan, E. L. (2016). A social capital perspective on the mentoring of undergraduate life science researchers: An empirical study of undergraduate-postgraduate-faculty triads. CBE-Life Sciences Education, 15(2), ar16.

Allen, T. D., Day, R., \& Lentz, E. (2005). The role of interpersonal comfort in mentoring relationships. Journal of Career Development, 31, 155-169.

Anaya, G., \& Cole, D. G. (2001). Latina/o student achievement: Exploring the influence of student-faculty interactions on college grades. Journal of College Student Development, 42(1), 3-14.

Banchefsky, S., Westfall, J., Park, B., \& Judd, C. M. (2016). But you don't look like a scientist! Women scientists with feminine appearance are deemed less likely to be scientists. Sex Roles, 75(3-4), 95-109.

Bevan, V., \& Learmonth, M. (2013). "I wouldn't say it's sexism, except that... It's all these little subtle things": Healthcare scientists' accounts of gender in healthcare science laboratories. Social Studies of Science, 43(1), 136-158.

Burgin, S. R., \& Sadler, T. D. (2016). Learning nature of science concepts through a research apprenticeship program: A comparative study of three approaches. Journal of Research in Science Teaching, 53(1), 31-59.

Butler, J. (2011). Bodies that matter: On the discursive limits of sex. Abington, UK: Routledge.

Carlone, H. B., \& Johnson, A. (2007). Understanding the science experiences of successful women of color: Science identity as an analytic lens Journal of Research in Science Teaching, 44(8), 1187-1218. 
Cech, E., Rubineau, B., Silbey, S., \& Seron, C. (2011). Professional role confidence and gendered persistence in engineering. American Sociological Review, 76(5), 641-666.

Chang, M. J., Sharkness, J., Hurtado, S., \& Newman, C. B. (2014). What matters in college for retaining aspiring scientists and engineers from underrepresented racial groups. Journal of Research in Science Teaching, 51(5), 555-580.

Chen, X. (2009). Students who study science, technology, engineering, and mathematics (STEM) in postsecondary education (NCES 2009-161). Washington, DC: National Center for Education Statistics.

Clark Blickenstaff, J. (2005). Women and science careers: Leaky pipeline or gender filter? Gender and Education, 17(4), 369-386

Cole, D., \& Espinoza, A. (2008). Examining the academic success of Latino students in science technology engineering and mathematics (STEM) majors. Journal of College Student Development, 49(4), 285-300.

Collins, P. H. (2000). Black feminist thought: Knowledge, consciousness, and the politics of empowerment (2nd ed.). New York: Routledge.

Conger, D., \& Long, M. C. (2010). Why are men falling behind? Gender gaps in college performance and persistence. Annals of the American Academy of Political and Social Science, 627(1), 184-214.

Corbin, J., \& Strauss, A. L. (2014). Basics of qualitative research: Techniques and procedures for developing grounded theory. Thousand Oaks, CA Sage.

Crisp, G., \& Cruz, I. (2009). Mentoring college students: A critical review of the literature between 1990 and 2007. Research in Higher Education 50(6), 525-545.

Crisp, G., Nora, A., \& Taggart, A. (2009). Student characteristics, pre-college, college, and environmental factors as predictors of majoring in and earning a STEM degree: An analysis of students attending a Hispanic serving institution. American Educational Research Journal, 46(4), 924-942.

Danielsson, A. T. (2012). Exploring woman university physics students "doing gender" and "doing physics." Gender and Education, 24(1), 25-39.

Dawson, A. E., Bernstein, B. L., \& Bekki, J. M. (2015). Providing the psychosocial benefits of mentoring to women in STEM: CareerWISE as an online solution. New Directions for Higher Education, 2015(171), 53-62.

Desmond, M., \& López Turley, R. N. (2009). The role of familism in explaining the Hispanic-White college application gap. Social Problems, 56(2), 311-334.

Dolan, E. L., \& Johnson, D. (2009). Toward a holistic view of undergraduate research experiences: An exploratory study of impact on graduate/postdoctoral mentors. Journal of Science Education and Technology, 18(6), 487.

Dolan, E. L., \& Johnson, D. (2010). The undergraduate-postgraduate-faculty triad: Unique functions and tensions associated with undergraduate research experiences at research universities. CBE-Life Sciences Education, 9(4), 543-553.

Dooley, D. A., Mahon, R. M., \& Oshiro, E. A. (2004). An undergraduate research opportunity: Collaboration between undergraduate and graduate students. Journal of Food Science Education, 3(1), 8-13.

Dreher, G. F., \& Cox, T. H. (1996). Race, gender and opportunity: A study of compensation attainment and the establishment of mentoring relationships. Journal of Applied Psychology, 81, 297-308.

Ecklund, E. H., Lincoln, A. E., \& Tansey, C. (2012). Gender segregation in elite academic science. Gender \& Society, 26(5), 693-717.

Elliott, R., Strenta, A. C., Adair, R., Matier, M., \& Scott, J. (1996). The role of ethnicity in choosing and leaving science in highly selective institutions. Research in Higher Education, 37(6), 681-709.

Feeney, M. K., \& Bozeman, B. (2008). Mentoring and network ties. Human Relations, 61(12), 1651-1676.

Feldman, A., Divoll, K. A., \& Rogan-Klyve, A. (2013). Becoming researchers: The participation of undergraduate and graduate students in scientific research groups. Science Education, 97(2), 218-243.

Glass, J. L., Sassler, S., Levitte, Y., \& Michelmore, K. M. (2013). What's so special about STEM? A comparison of women's retention in STEM and professional occupations. Social Forces, 92(2), 723-756.

Gonzalez, C. (2001). Undergraduate research, graduate mentoring, and the university's mission. Science, 293(5535), 1624-1626.

Gouvea, J. (2017). Insights from small-N studies. CBE-Life Sciences Education, 16, fe4. doi: 10.1187/cbe.17-06-0110
Greenfield, S., \& Peters, J. W. (2002). Set fair: A report on women in science, engineering, and technology from the Baroness Greenfield CBE to the Secretary of State for Trade and Industry. London: Department of Trade and Industry.

Griffith, A. L. (2010). Persistence of women and minorities in STEM field majors: Is it the school that matters?. Economics of Education Review, 29(6), 911-922.

Harsh, J. A., Maltese, A. V., \& Tai, R. H. (2012). A perspective of gender differences in chemistry and physics undergraduate research experiences. Journal of Chemical Education, 89(11), 1364-1370.

Hirshfield, L. E. (2015). "I just did everything physically possible to get in there"-How men and women chemists enact masculinity differently. Social Currents, 2(4), 324-340.

Hirshfield, L. E., \& Joseph, T. D. (2012). "We need a woman, we need a black woman": Gender, race, and identity taxation in the academy. Gender and Education, 24(2), 213-227.

Hunter, A., Laursen, S. L., \& Seymour, E. (2007). Becoming a scientist: The role of undergraduate research in students' cognitive, personal, and professional development. Science Education, 91(1), 36-74.

Hurtado, S., Cabrera, N. L., Lin, M. H., Arellano, L., \& Espinosa, L. L. (2009). Diversifying science: Underrepresented student experiences in structured research programs. Research in Higher Education, 50(2), 189-214

Hurtado, S., Chang, J. C., Sáenz, V. B., Espinosa, L. L., Cabrera, N. L., \& Cerna, O. S. (2007). Predicting transition and adjustment to college: Minority biomedical and behavioral science students' first year of college. Research in Higher Education, 48(7), 841-887.

Jackson, D. L., Starobin, S. S., \& Laanan, F. S. (2013). The shared experiences: Facilitating successful transfer of women and underrepresented minorities in STEM fields. New Directions for Higher Education, 2013(162), 69-76.

Johnson, D. R. (2012). Campus racial climate perceptions and overall sense of belonging among racially diverse women in STEM majors. Journal of College Student Development, 53(2), 336-346.

Johnson, J., \& Bozeman, B. (2012). Perspective: Adopting an asset bundle model to support and advance minority students' careers in academic medicine and the scientific pipeline. Academic Medicine, 87(11), 1488.

Jones, B. D., Ruff, C., \& Paretti, M. C. (2013). The impact of engineering identification and stereotypes on undergraduate women's achievement and persistence in engineering. Social Psychology of Education, 16(3), 471-493

Knobloch-Westerwick, S., Glynn, C. J., \& Huge, M. (2013). The Matilda effect in science communication: An experiment on gender bias in publication quality perceptions and collaboration interest. Science Communication, 35(5), 603-625

Kuh, G. D., Kinzie, J., Schuh, J. H., Whitt, E. J., \& Associates. (2010). Student success in college: Creating conditions that matter. Hoboken, NJ: John Wiley $\&$ Sons.

Linn, M. C., Palmer, E., Baranger, A., Gerard, E., \& Stone, E. (2015). Undergraduate research experiences: Impacts and opportunities. Science, 347(6222), 1261757

Linneman, T. J. (2013). Gender in Jeopardy! Intonation variation on a television game show. Gender \& Society, 27(1), 82-105.

Lockwood, P. (2006). "Someone like me can be successful": Do college students need same-gender role models? Psychology of Women Quarterly, $30,36-46$

Lopatto, D. (2004). Survey of undergraduate research experiences (SURE): First findings. Cell Biology Education, 3(4), 270-277.

Lopatto, D. (2007). Undergraduate research experiences support science career decisions and active learning. CBE-Life Sciences Education, 6(4), 297-306.

Lopatto, D., \& Tobias, S. (2010). Science in solution: The impact of undergraduate research on student learning. Washington, DC: Council on Undergraduate Research.

Mau, W. C. J. (2016). Characteristics of US students that pursued a STEM major and factors that predicted their persistence in degree completion. Universal Journal of Educational Research, 4(6), 1495-1500.

McCabe, J. M. (2016). Connecting in college: How friendship networks matter for academic and social success. Chicago: University of Chicago Press. 
Monroe, K., Ozyurt, S., Wrigley, T., \& Alexander, A. (2008). Gender equality in academia: Bad news from the trenches, and some possible solutions. Perspectives on Politics, 6(2), 215-233.

Morales, D. X., Grineski, S. E., \& Collins, T. W. (2018). Effects of gender concordance in mentoring relationships on summer research experience outcomes for undergraduate students. Science Education, 102(5), 1029-1050.

Morris, E. W. (2012). Learning the hard way: Masculinity, place, and the gender gap in education. New Brunswick, NJ: Rutgers University Press.

Moss-Racusin, C. A., Dovidio, J. F., Brescoll, V. L., Graham, M. J., \& Handelsman, J. (2012). Science faculty's subtle gender biases favor male students Proceedings of the National Academy of Sciences USA, 109(41), 1647416479

National Science Foundation, Division of Science Resources Statistics. (2009). Women, Minorities, and Persons with Disabilities in Science and Engineering NSF 09-305. Arlington, VA. Retrieved from www.nsf.gov/ statistics/wmpd/

Nora, A., \& Crisp, G. (2007). Mentoring students: Conceptualizing and validating the multi-dimensions of a support system. Journal of College Student Retention: Research, Theory \& Practice, 9(3), 337-356.

Ong, M., Wright, C., Espinosa, L., \& Orfield, G. (2011). Inside the double bind: A synthesis of empirical research on undergraduate and graduate women of color in science, technology, engineering, and mathematics. Harvard Educational Review, 81(2), 172-209.

Oseguera, L., Hurtado, S., Denson, N., Cerna, O., \& Saenz, V. (2006). The characteristics and experiences of minority freshmen committed to biomedical and behavioral science research careers. Journal of Women and Minorities in Science and Engineering, 12(2-3), 155-177.

Ostrove, J. M., \& Long, S. M. (2007). Social class and belonging: Implications for college adjustment. Review of Higher Education, 30(4), 363-389.

Ovink, S. M. (2014). "They always call me an investment": Gendered familism and Latino/a college pathways. Gender \& Society, 28(2), 265-288.

Ovink, S. M., \& Veazey, B. D. (2011). More than "getting us through": A case study in cultural capital enrichment of underrepresented minority undergraduates. Research in Higher Education, 52(4), 370-394.

Paglis, L. L., Green, S. G., \& Bauer, T. N. (2006). Does adviser mentoring add value? A longitudinal study of mentoring and doctoral student outcomes. Research in Higher Education, 47(4), 451-476.

Prunuske, A., Wilson, J., Walls, M., Marrin, H., \& Clarke, B. (2016). Efforts at broadening participation in the sciences: An examination of the mentoring experiences of students from underrepresented groups. CBE-Life Sciences Education, 15(3), ar26.

Rainey, K., Dancy, M., Mickelson, R., Stearns, E., \& Moller, S. (2018). Race and gender differences in how sense of belonging influences decisions to major in STEM. International Journal of STEM Education, 5(1), 10.

Rhoton, L. A. (2011). Distancing as a gendered barrier: Understanding women scientists' gender practices. Gender \& Society, 25(6), 696-716.

Rosenthal, L., London, B., Levy, S. R., \& Lobel, M. (2011). The roles of perceived identity compatibility and social support for women in a single-sex STEM program at a co-educational university. Sex Roles, 65(9-10), 725-736

Sallee, M. W. (2011). Performing masculinity: Considering gender in doctoral student socialization. Journal of Higher Education, 82(2), 187-216.

Shapiro, C. A., \& Sax, L. J. (2011). Major selection and persistence for women in STEM. New Directions for Institutional Research 152, 5-18.

Shepherd, M. A. (2016). Effects of race/ethnicity, gender, and intonation on secondary science teachers' evaluation of spoken responses. Urban Education, https://journals.sagepub.com/doi/10.1177/0042085916660346

Small, M. L. (2009). "How many cases do I need?" On science and the logic of case selection in field-based research. Ethnography, 10(1), 5-38.

Sosik, J. J., \& Godshalk, V. M. (2005). Examining gender similarity and mentor's supervisory status in mentoring relationships. Mentoring and Tutoring, 13(1), 39-52

Stolle-McAllister, K. (2011). The case for Summer Bridge: Building social and cultural capital for talented Black STEM students. Science Educator, 20(2), 12.

Stout, J. G., Dasgupta, N., Hunsinger, M., \& McManus, M. A. (2011). STEMing the tide: Using ingroup experts to inoculate women's self-concept in science, technology, engineering, and mathematics (STEM). Journal of Personality and Social Psychology, 100(2), 255.

Strayhorn, T. L. (2010). When race and gender collide: Social and cultural capital's influence on the academic achievement of African American and Latino males. Review of Higher Education, 33(3), 307-332.

Strayhorn, T. L. (2012). College students' sense of belonging: A key to educational success for all students. New York: Routledge.

Syed, M., Azmitia, M., \& Cooper, C. R. (2011). Identity and academic success among under-represented ethnic minorities: An interdisciplinary review and integration. Journal of Social Issues, 67(3), 442-468. Retrieved April 19, 2019, from http://citeseerx.ist.psu.edu/viewdoc/download?doi=10 1.1.450.163\&rep=rep1\&type $=\mathrm{pdf}$

Thiry, H., \& Laursen, S. L. (2011). The role of student-advisor interactions in apprenticing undergraduate researchers into a scientific community of practice. Journal of Science Education and Technology, 20(6), 771-784.

Thompson, M. D. (2001). Informal student-faculty interaction: Its relationship to eductional gains in science and mathematics among community college students. Community College Review, 29(1), 35-57.

U.S. Commission on Civil Rights. (2010). Encouraging minority students to pursue science, technology, engineering and math careers. A briefing before the United States Commission on Civil Rights held in Washington, D.C. (Briefing report). Washington, DC. Retrieved April 19, 2019, from http://citeseerx.ist.psu.edu/viewdoc/download?doi=10.1.1.450 .163\&rep=rep1\&type $=$ pdf

Weiss, R. S. (1995). Learning from strangers: The art and method of qualitative interview studies. Simon and Schuster.

West, C., \& Zimmerman, D. H. (1987). Doing gender. Gender \& Society, 1(2), 125-151.

Zirkel, S. (2002). Is there a place for me? Role models and academic identity among white students and students of color. Teachers College Record, 104(2), 357-376 